Reproductive aspects of cultured humpback grouper ... (Sari Budi Moria Sembiring)

\title{
REPRODUCTIVE ASPECTS OF CULTURED HUMPBACK GROUPER (Cromileptes altivelis) FOR SUPPORTING SEED PRODUCTION
}

\author{
Sari Budi Moria Sembiring\#, John Harianto Hutapea, Ahmad Muzaki, \\ Ida Komang Wardana, Ni Wayan Widya Astuti, and Retno Andamari \\ Research and Development Institute for Mariculture, Gondol, Bali
}

(Received 17 December 2013; Accepted 8 April 2014)

\begin{abstract}
Humpback grouper (Cromileptes altivelis) has been successfully spawned in 2000 by IMRAD (Institute of Mariculture Research and Development) and there are already the third generation (F3) currently. The reproductive aspects need to be studied to support the success of seed production. Humpback grouper reared in floating cage (F1 and F3) had matured (gonad stage 4) while F2 fish reared in concrete tanks has spawned. Gonadal maturity stage of 38 fishes from first generation (F1) and 35 fishes from the third generation were observed in June 2013 and compared to gonadal maturity stage of 18 fishes from the second generation observed in June 2009 . Samples were measured in total length and body weight and gonads were taken for histology preparation to determine gonadal maturity stage and the sex. From the histological observation of the gonads, it showed that all female humpback grouper were in early maturity stage (stage I and II) with gonadal maturity index between $0.12 \%$ and $5.45 \%$ Further, it was observed that the same gonad was found in different maturity stage and concluded that humpback groupers were multiple spawners (asynchronous). By determining gonadal maturity level, it was also known the minimum size for grouper ready to spawn.
\end{abstract}

KEYWORDS: gonad, humpback grouper, Cromileptes altivelis, F1, F2, and F3

\section{INTRODUCTION}

Northern part of Bali, mainly in Gerokgak District Buleleng Regency is the center for marine aquaculture, especially milkfish and several grouper species of hatchery breed production, and it has been recognized nationally and even internationally. Many of grouper seeds were exported for both domestic and foreign markets. Several grouper species cultured include coral trout grouper (Plectropomus leopardus), humpback grouper (Cromileptes altivelis) and some hybrid grouper seeds.
Humpback grouper was cultured due to its high demand, especially for China and Hong Kong markets. In 2008, 1,470 tons of live wild grouper were exported from Bali to HongKong, Taiwan, Singapore, USA, and other countries (Anonymous, 2009). Humpback grouper is highly preferred by consumers in this region due to its prime taste and its juvenile is favorite ornamental fish.

To keep hatchery and aquaculture of humpback grouper sustainable, wild broodstocks dependency should be gradually reduced and replaced with domesticated broodstocks. To

\# Corresponding author. Research and Development Institute for Mariculture, Jl. Br. Gondol, Kec. Gerokgak, Kab. Buleleng, Kotak Pos 140, Singaraja, Bali 81101, Indonesia. Tel.: +62 36292278 E-mail: moriasembiring@yahoo.co.id 
support the success of grouper hatchery, the reproductive aspects of the cultured broodstocks, particularly to determine the mature size of cultured humpback grouper broodstock need to be studied.

\section{MATERIAL AND METHOD}

Three generation of humpback grouper were used in this experiment to compare the gonadal development of each generation. Samples of candidate broodstock of Humpback grouper were attained from the first generation (38 fishes) and the third generarion (35 fishes) from floating cage at IMRAD (Institute of Mariculture Reseach and Development) and the second generation (150 fishes) from concrete tanks of IMRAD (Tridjoko \& Gunawan, 2010). All the fish had the same age, i.e. 36 months. The total length and body weight of fish were measured and gonad was weighed then preserved for histology preparation and stained using Haematoxylene Eosin following Luna (1968). The histology of gonads were observed under microscope to determine maturity stage. The gonads were classified following Hunter \& Goldberg (1980); Cyrus \& Blaber (1984); Andamari et al. (1998) as follows:

\section{Class I : Not developed \\ Class II : Developed \\ Class III : Early maturation \\ Class IV : Almost mature \\ Classs V : Mature \\ Class VI : Over riped}

For class IV and V, the oocyte were counted to know the fecundity and determined following formula from Bagenal (1978) as follows:

$$
F=\frac{W g}{W s} \times n
$$

where:

$$
\begin{aligned}
& \mathrm{F}=\text { Batch fecundity } \\
& \mathrm{Wg}=\text { Gonad weight }(\mathrm{g}) \\
& \mathrm{Ws}=\text { Weight of gonad sub sample }(\mathrm{g}) \\
& \mathrm{n}=\text { Total number of fishes }
\end{aligned}
$$

The relative fecundity were determined following Effendie (1997), while for the male broodstock the level of maturity were determined by the presence of spermatozoa.

The formula to determine the index of gonadal maturity (GSI/ Gonadosomatic Index) as follows :

$$
\mathrm{GSI}=(\mathrm{Wg} / \mathrm{W}) \times 100 \%
$$

where:

$$
\begin{aligned}
& \mathrm{Wg}=\text { Gonad weight }(\mathrm{g}) \\
& \mathrm{W}=\text { Fish weight }(\mathrm{g})
\end{aligned}
$$

\section{Relation of Total Length and Body Weight}

According to Effendie (1997), weight of the fish can be considered as a function of length and usually follows the cubic law. If the fish do not follow the cubic law so the fish growth is allometric (does not equal to 3 ).

The formula of relation between total length and body weight (Royce, 1984) is as follows:

$$
\mathrm{W}=a L^{b}
$$

where:

$\mathrm{W}=$ Body weight $(\mathrm{g})$

$\mathrm{L}=$ Total length $(\mathrm{cm})$

$\mathrm{a}$ and $\mathrm{b}=$ Constant

\section{RESULT AND DISCUSSION}

The description of 38 fishes of humpback grouper F1, 18 fishes of F2 and 35 fishes of F3 were presented in Table 1 while relation of total length and body weight was presented in Figure 1, 2, and 3.

From the F1 fish sample, the fecundity of 5 fishes can be determined. According to Tridjoko \& Gunawan (2010), humpback grouper was ready to be broodstock when it reached $510-750 \mathrm{~g}$ for the female, and more than $754 \mathrm{~g}$ for male. It means that male broodstocks are bigger than female one. Humpback grouper is an hermaprodite species. The sex will change from female to male (protogynous hermaphrodite) according to their size. According to the size, the fish sample of humpback grouper cultured was ready to be female broodstock, because most of the samples were identified as female. It means that the gonads were develope but the maturity still had to be identified.

Based on Table 1, 97\% of the 38 fishes of F1 samples were female which mostly in Class I and II of gonadal maturity while the other 5 fishes were in Class IV. Male was not found from all fish sample. Average total length and body weight of fish were $29.20 \mathrm{~cm}$ and 406.58 g, respectively.

The gonads of 18 fishes of humpback grouper of the second generation were observed, 
Reproductive aspects of cultured humpback grouper ... (Sari Budi Moria Sembiring)

Table 1. Total length and body weight 38 fishes humpback grouper of first generation (F1), 18 fishes of second generation (F2) and 35 fishes of third generation (F3)

\begin{tabular}{|c|c|c|c|c|c|c|c|}
\hline \multirow{2}{*}{ Sex } & \multirow{2}{*}{$\mathbf{n}$} & \multicolumn{3}{|c|}{ Total length (cm) } & \multicolumn{3}{|c|}{ Body weight (g) } \\
\hline & & Min & Max & Average \pm SE & Min & Max & Average $\pm S E$ \\
\hline \multicolumn{8}{|l|}{$\mathbf{F 1}$} \\
\hline Female & 37 & 21.0 & 35.0 & $29.26 \pm 0.44$ & 190 & 690 & $410.00 \pm 16.95$ \\
\hline Not Identified & 1 & 27.0 & 27.0 & $27.00 \pm-$ & 280 & 280 & $280.00 \pm-$ \\
\hline Total & 38 & 21.0 & 35.0 & $29.20 \pm 0.43$ & 190 & 690 & $406.58 \pm 16.85$ \\
\hline \multicolumn{8}{|l|}{$\mathbf{F} 2$} \\
\hline Male & 4 & 27.0 & 32.7 & $29.25 \pm 1.30$ & 362 & 542 & $417.50 \pm 42.08$ \\
\hline Female & 14 & 26.3 & 33.0 & $28.91 \pm 0.52$ & 326 & 548 & $414.64 \pm 18.93$ \\
\hline Total & 18 & 26.3 & 33.0 & $28.98 \pm 0.48$ & 326 & 548 & $415.28 \pm 16.81$ \\
\hline \multicolumn{8}{|l|}{ F3 } \\
\hline Male & 4 & 27.0 & 31.0 & $28.75 \pm 0.83$ & 280 & 460 & $347.50 \pm 39.02$ \\
\hline Female & 28 & 21.4 & 34.5 & $27.47 \pm 0.54$ & 128 & 750 & $328.89 \pm 26.31$ \\
\hline Hermaphrodite & 1 & 27.3 & 27.3 & $27.30 \pm-$ & 250 & 250 & $250.00 \pm-$ \\
\hline Not identified & 2 & 23.0 & 27.0 & $25.00 \pm 2.00$ & 205 & 320 & $262.50 \pm 57.50$ \\
\hline Total & 35 & 21.4 & 34.5 & $27.47 \pm 0.46$ & 128 & 750 & $324.97 \pm 21.77$ \\
\hline
\end{tabular}

$87 \%$ of samples were female while the remaining were male ( $22 \%)$. The average total length and body weight of female and male humpback grouper from the second generation had similar range (Table 1), $29.25 \mathrm{~cm}$ and $417.50 \mathrm{~g}$ for male and $28.91 \mathrm{~cm}$ and $414.64 \mathrm{~g}$ for female.

From 35 fishes of humpback grouper from the third generation, $11.4 \%$ samples were male, $80 \%$ samples were female, $2.9 \%$ samples were hermaphrodite and 5.7\%were un- identified. On the other hand, the average of total length and body weight of humpback grouper F3 were smaller compared to the first and the second generation, which were $27.47 \mathrm{~cm}$ and 324.97 $\mathrm{g}$, respectively. Based on the observation of all samples, it can be concluded that humpback grouper in size of $21-35 \mathrm{~cm}$ for total length and $128-750 \mathrm{~g}$ of body weight were mostly female. In order to get male broodstock, the fish should be bigger than that size.

\section{Relation of Total Length and Body Weight}

The relation of total length and body weight of humpback grouper from the first generation (F1) presented in Figure 1 with value of $b=$
2.4367, Figure 2 for the second generation (F2) with $b=2.1794$ and Figure 3 for the third generation (F3) with $b=3.2757$. All $b$ values did not equal to 3 , meaning that the humpback grouper growth is allometric. The b value of F1 and $\mathrm{F} 2$ were $<3$, that means their growth were allometric negative. The allometric negative means that length growth of fishes is faster than weight growth. The $b$ value of F3 were $>$ 3 , means that their growth were allometric positive. The allometric positive means that weight growth of fish is faster than length growth (Effendie, 1997). Allometric negative growth indicated that fish were focus on increasing their size especially for length but not their gonadal development. It means that the gonads were established but still in early stage. When the gonads matured, the volume and weight also increased, and that contributed to body weight of fish. Therefore the growth pattern would change to allometric positive. Allometric positive also could be happened if the fish fat. Their weight increased faster than their length. In this case; with the same age; the weight development of humpback grouper could be faster than F1 and F2, so the fish were fatter. Another possibility is the gonadal development of humpback grouper F3 could be 
Indonesian Aquaculture Journal Vol. 9 No. 1, 2014

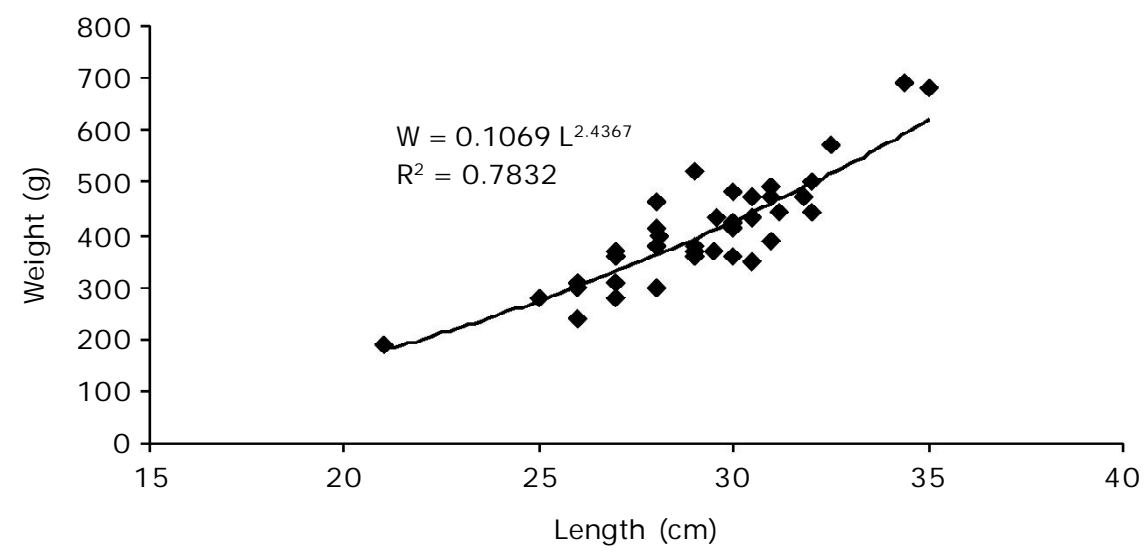

Figure 1. Relation between total length and body weight of humpback grouper of first generation $(n=38)$

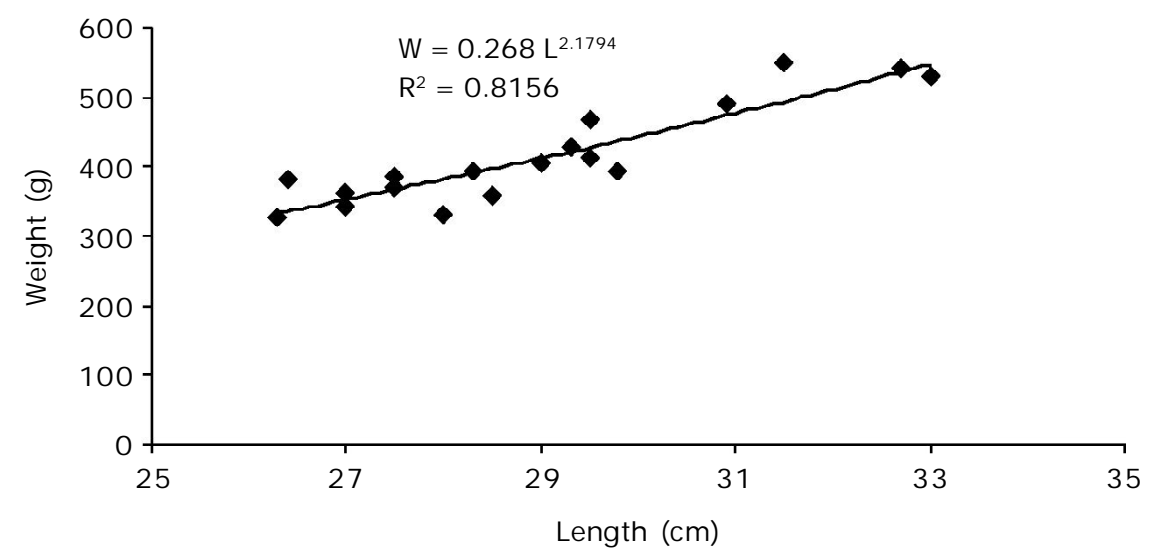

Figure 2. Relation between total length and body weight of humpback grouper of the second generation $(n=18)$

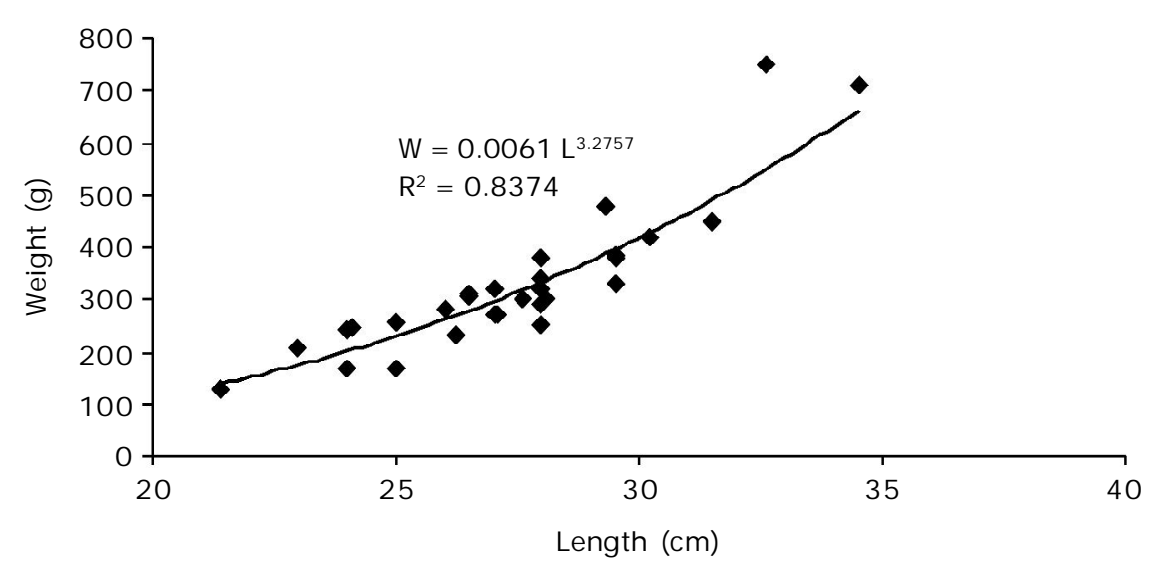

Figure 3. Relation between total length and body weight of humpback grouper of the third generation $(n=35)$ 
faster than F1 and F2. This statement should be proved by gonads observation and histological sections.

\section{The level of Gonadal Maturity}

Based on observation of gonadal maturity, 32 of 37 fishes $(86,5 \%$ humpback grouper from the first generation were in early level of maturity, class I and II, while 5 of 32 fishes $(13,5 \%)$ were in class IV and one sample was un-identified. The second and the third generation of humpback grouper were in class I- IV. This data indicated that female gonadal development of humpback grouper F2 and F3 were faster than $\mathrm{F} 1$.

According to histological analysis, it showed humpback grouper is asynchronous where there were several levels of maturity inside one gonad, so it could spawn multiple times in a single spawning season. Gonad histological section showed that there were a range of undeveloped oocytes until almost mature stage in one fish gonad (Figure 4).

Figure 5 shows the oocytes of the first generation humpback grouper were in class IV

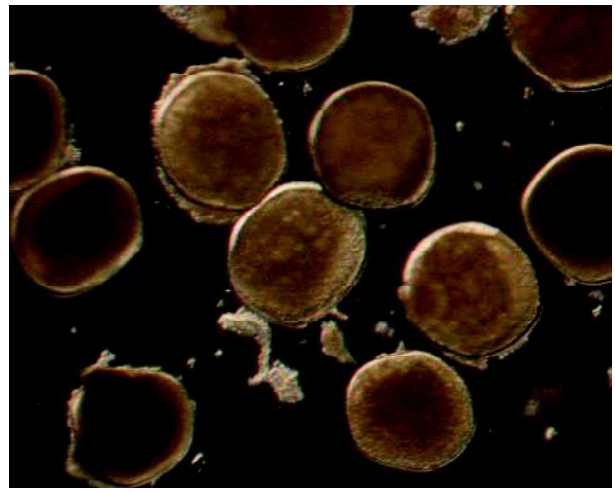

Figure 5. Oocyte of humpback grouper of the first generation $(80 \mathrm{X})$

having globular shape with a maximum diameter of 550 micrometer $(\mu \mathrm{m})$ and it was classified as a matured stage to ready to spawn stage.

Figure 6 shows the distribution of oocytes diameters on gonad of the first generation humpback grouper. The range of oocytes diameters was $325-550 \mu \mathrm{m}$. Median of oocytes size was $425 \mu \mathrm{m}$. From the distribution of oo-
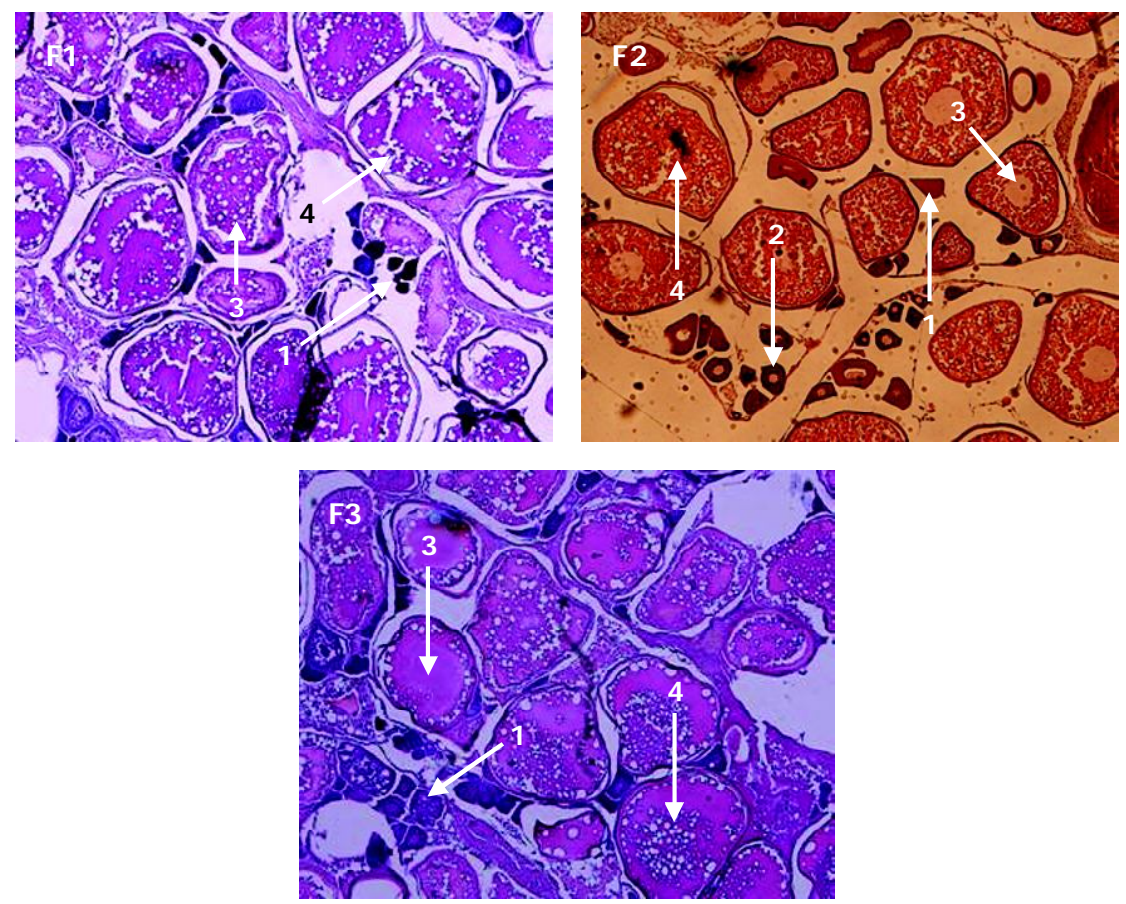

Figure 4. Gonads histological section of female humpback group of the first generation (F1), the second generation (F2) and the third generation (F3) (HEX 100) 
Indonesian Aquaculture Journal Vol. 9 No. 1, 2014

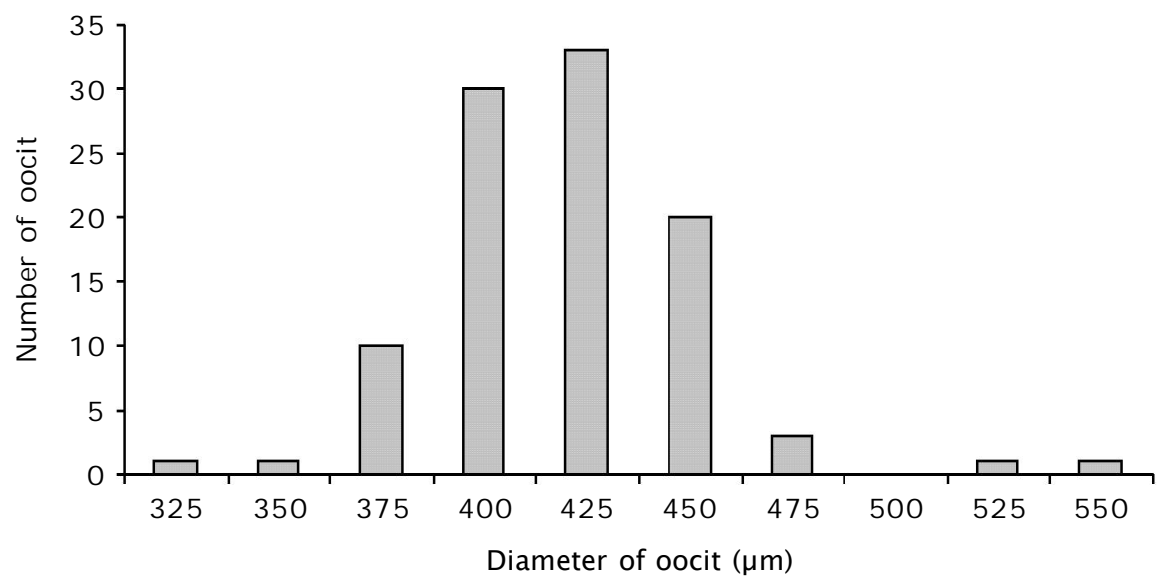

Figure 6. Relation between the diameter and number of oocyte of humpback grouper of the first generation ( $n=100$ fishes)

cytes it shows that oocytes were still developing and getting bigger and were not ready for spawning. According to Tridjoko \& Gunawan (2010), egg diameter of early spawned humpback grouper was more than $800 \mu \mathrm{m}$.

Table 2 shows the relation of the fecundity with total length and body weight of F1 humpback grouper. The fecundity ranged from 92,153 to 150,726 eggs with relative fecundity values ranged from 192.00 to 399.79 . This suggests that the observed sample of fish, fish weight and length do not specify the fish fecundity. The eggs diameter of this fish ranged from $325 \mu \mathrm{m}$ to $550 \mu \mathrm{m}$ (Figure 6). From the observation, the gonads maturity were classified as stage IV.

\section{Index of Gonadal Maturity}

Table 3 shows gonadal maturity index on three generations of humpback grouper. Go-
Table 3. Gonadal maturity index of humpback grouper

\begin{tabular}{lllll}
\hline \multirow{2}{*}{ Generation } & $\mathbf{n}$ & \multicolumn{3}{c}{ GSI (\%) } \\
\cline { 3 - 5 } & & Min & Max & Mean \pm SE \\
\hline First (F-1) & 38 & 0.18 & 5.45 & $2.16 \pm 0.22$ \\
Second (F-2) & 18 & 0.12 & 4.53 & $2.20 \pm 0.33$ \\
Third (F-3) & 35 & 0.19 & 2.32 & $0.84 \pm 0.07$ \\
\hline
\end{tabular}

nadal maturity index or gonadosomatic index (GSI, \% was used as a prediction tool to measure the level of maturity. GSI in this study ranged from 0.12 to 5.45 . The mature coral trout grouper have GSI greater than 2 (Andamari $\&$ Suwirya, 2010) whereas in this study humpback grouper gonads did not mature yet. This indicated that for mature humpback grouper, the GSI value must be $>5.45 \%$

Table 2. Relation between fecundity with total length and body weight of humpback grouper of the first generation (F1)

\begin{tabular}{ccccc}
\hline $\begin{array}{c}\text { Total } \\
\text { length } \\
\text { (cm) }\end{array}$ & $\begin{array}{c}\text { Body } \\
\text { weight } \\
\text { (g) }\end{array}$ & $\begin{array}{c}\text { Gonad } \\
\text { weight } \\
\text { (g) }\end{array}$ & $\begin{array}{c}\text { Fecundity } \\
\text { (eggs) }\end{array}$ & $\begin{array}{c}\text { Fecundity } \\
\text { relative } \\
\text { (eggs/g BM) }\end{array}$ \\
\hline 31.0 & 490 & 26.7 & 132,726 & 270.87 \\
31.0 & 470 & 16.3 & 99,956 & 237.99 \\
30.0 & 480 & 15.7 & 92,153 & 192.00 \\
28.0 & 460 & 18.2 & 150,726 & 327.66 \\
30.0 & 300 & 15.1 & 119,937 & 399.79 \\
\hline
\end{tabular}


Based on the gonadal observations of all generations of humpback grouper (91 fishes) gonadal maturity index ranged from 0.12 to 5.45 and mostly in early level maturity.

Figure 7, 8, and 9 showed the relation between body weight and GSI. The GSI of F1 ranged from $0 \%$ to $6 \%$ from samples which weight were higher than $150 \mathrm{~g}$. GSI of F2 ranged from $0 \%$ to $3.5 \%$ from samples which weight were higher than $350 \mathrm{~g}$. And GSI of F3 ranged from $0 \%$ to $2.5 \%$ from samples which weight were higher than $150 \mathrm{~g}$. There were no pattern between two variables. It means that body weight did not affect the GSI. There is no a direct relationship between GSI and fish length or fish weight in coral trout grouper Plectropomus leopardus. This statement means that the longer or heavier of fish do not necessarily has a higher GSI. The stage of gonad maturity is possibly more directly linked to timing of spawning season (Andamari \& Suwirya, 2010).

According to Tridjoko \& Gunawan (2000) cultured humpback grouper female spawned for the first time when its weight reach $>700 \mathrm{~g}$ with an average fecundity of 150,000 per fish. While in this study the size of the humpback grouper was still in the range of $128-750 \mathrm{~g}$ (Table 1) and no single fish was mature.

\section{CONCLUSION}

Humpback grouper (Cromileptes altivelis) is asyncronus or multiple times spawners and it was not able to differentiate between male

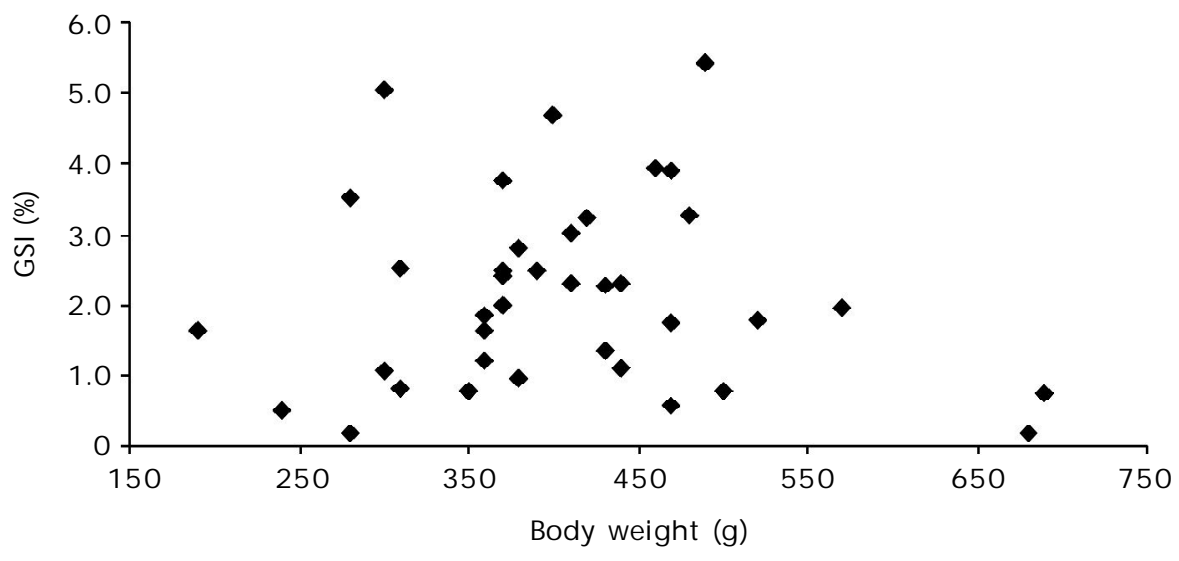

Figure 7. Relation between body weight and gonadosomatic index (GSI) of humpback grouper of the first generation

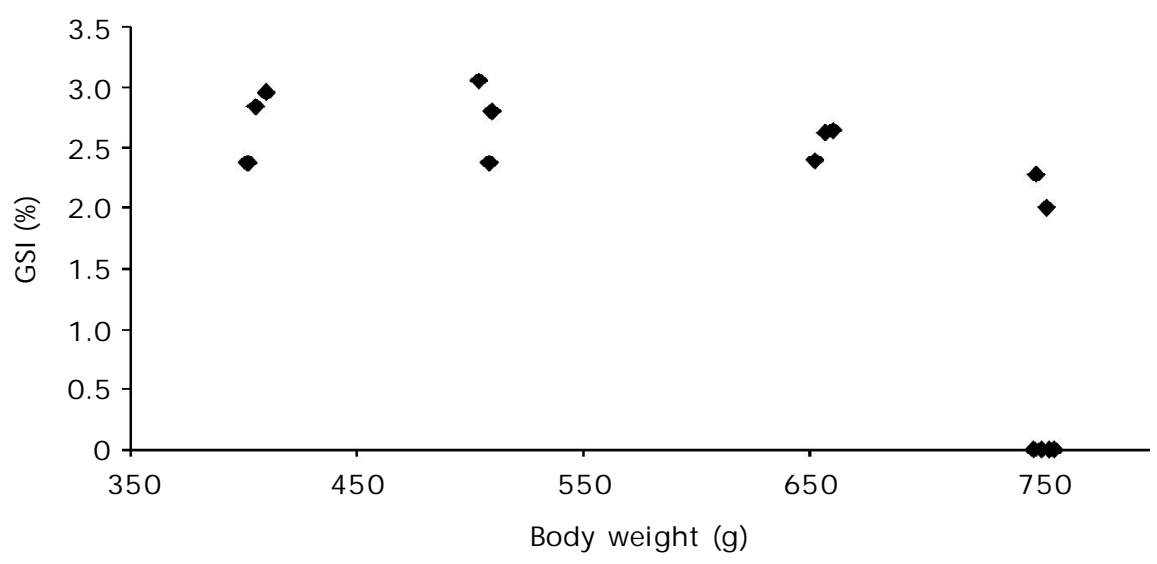

Figure 8. Relation between body weight and gonadosomatic index (GSI) of humpback grouper of the second generation 


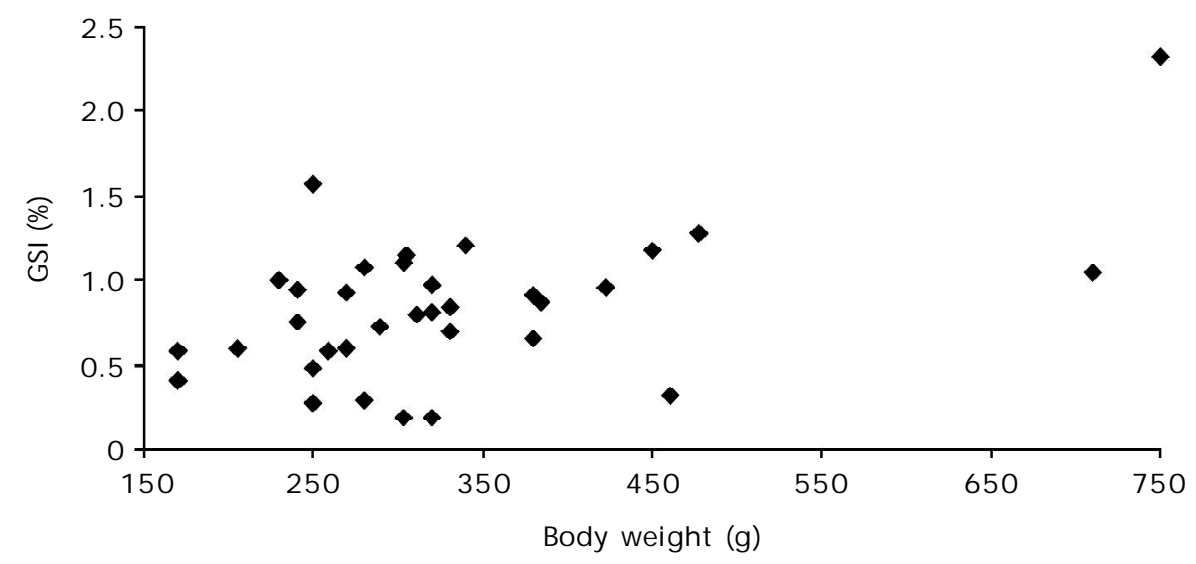

Figure 9. Relation between body weight and gonadosomatic index (GSI) of humpback grouper of the third generation

and female fish morphologically. For broodstock selection, it was suggested to use fish with the size more than $700 \mathrm{~g}$ and $35 \mathrm{~cm}$ length. The fecundity range was 92,153150,726 eggs with average of 119,036 eggs.

\section{REFERENCES}

Anonymous. 2009. Annual report export fisheries production of Bali Province 2008. Fisheries and Marine District of Bali Province.

Andamari, R. \& Suwirya, K. 2010. Reproduction performance of wild broodstock coral trout (Plectropomus leopardus). Ind. Fish Res. J., 16(1): 41- 47.

Andamari, R., Farmer, M. Chodriyah, U., \& Susanto, A.N. 1998. Gonad maturity stages of anchovies (Encrasicholina heterolobus) from Bacan Island. Ind. Fish. Res. Journal, IV(2): 47- 51.

Bagenal, T.B. 1978. Methods for assessment of fish production in freshwater. IBP. Handbook (3) Blackwell Scientific Publications, Oxford, $253 \mathrm{pp}$.
Cyrus, D.P. \& Blaber, S.J.M. 1984. The reproductive biology of Gerres (Teleostei) Bleeker 1859, in Natal estuaries. J. Fish. Biol., 24: 491- 504.

Effendie, M.I. 1997. Fisheries biology. Yayasan Pustaka Nusatama. Yogyakarta, 163 pp.

Hunter, J.R. \& Goldberg, S.R. 1980. Spawning incidence and batch fecundity in northern anchovy Engraulis mordax. Fish. Bull. U.S., 77: 641-652.

Luna, L.G. 1968. Manual of histological staining methods of the armed forces. Institute of Pathology. $3^{\text {rd }}$ ed. McGraw- Hill, N.Y. p. 420- 432.

Royce, W.F. 1984. Introduction to the practice of fishery science. Academic Press. California, USA, $423 \mathrm{pp}$.

Tridjoko \& Gunawan. 2010. Eggs diameter observation of humpback grouper broodstock candidate (Cromileptes altivelis) second generation (F2) to support grouper breeding technology. Proceeding of Forum Inovasi Teknologi Akuakultur. p. 605- 610. 